\title{
AZ EMPLOYER BRANDING ÉS A STRESSZKEZELÉS SZEREPE A Z GENERÁCIÓS FIATALOK FOGLALKOZTATÁSÁBAN
}

\author{
Békési Nóra - Szücs Róbert Sándor
}

\begin{abstract}
Absztrakt: A munkáltatók sikerének kulcsa a munkaerőben, mint termelési tényezőben rejlik. A nemzetgazdasági mutatók tükrében látható, hogy a vállalatok számos nehézséggel küzdenek a HRM területén. Ilyen a képzett munkaerő iránti túlkereslet és az elöregedő társadalom negatív következményei. A helyzetet tovább súlyosbítja, hogy a munkaerő piacra már belépett vagy belépni készülő Z generáció különbözik minden eddigitől, ez az első digitális nemzedék. Szocializációjuk és a világgal való kapcsolatuk merőben eltér az idősebb korosztályétól. A munkahelyi stressz eddig is komoly akadályokat gördített a vállalatok elé. A stressz egyre nagyobb kihívássá vált napjainkban, tekintve, hogy a Z generáció sokkal inkább hajlamosabb a stresszre és szorongásra, mint a korábbi nemzedékek. Ez tovább fokozza a vállalatok fluktuációs problémáit. A megoldást az employer branding alkalmazásában látjuk, aminek célja a munkáltatók iránti elköteleződés kialakítása, növelése. Kutatásunkban az employer branding, a munkahelyi stressz és a $Z$ generációs fiatalok alkalmazásának összefüggéseit vizsgáljuk szakirodalmi források áttekintésével.
\end{abstract}

\begin{abstract}
The success of the employers can be found in the labour force, as a factor of production. In the reflection of the national economic indicators, it can be seen that many companies face several difficulties in the field of HRM. These can be the excessive demand for the well-educated working force or the negative consequences of the ageing society. The situation is getting more serious as the generation $\mathrm{Z}$ which has already entered or entering the labour market differ from every earlier generation, this is the first digital generation. Their socialization and relation to the world differ from the elderly ones. The occupational stress has already been rolling serious obstacles in front of the companies. Stress is getting a greater challenge nowadays, as the generation $\mathrm{Z}$ is more inclined to stress and anxiety than the earlier generation. Because of that the fluctuational problems of the companies are growing. In our view the solution is the use of the employer branding, which aims the development and growth of the commitment to the company and to the employer. In our paper we would like to study the relation of employer branding, occupational stress and the employment of generation $\mathrm{Z}$.
\end{abstract}

Kulcsszavak: Z generáció, employer branding, munkahelyi stressz, emberi erőforrás management

Keywords: generation Z, employer branding, occupational stress, human resource management

\section{Bevezetés}

A klasszikus közgazdaságtan csupán néhány termelési tényezővel számol. A termeléshez a klasszikus értelemben szükségünk van természeti tényezőkre, reál- és pénztőkére, munkaerőre és vállalkozóra, aki a termelési folyamatokat menedzseli. A klasszikus közgazdaságtan egyfajta plusz tényezőként tekint az információra. Globális világunk azonban gyökeresen megváltoztatta a termelési viszonyokat. Lengyel Imre 2003-ban az alábbiak szerint fogalmazott: „Az is jellemző, hogy az új ismeretek és új technológiák nagyon gyorsan elterjednek az egész Földön és beépülnek a termelési, üzleti folyamatokba, részben a multinacionális vállalatok hálózatai révén”. Főleg a tudásalapú gazdaságból származó néhány új eljárás (pl. új internetes avagy mobiltelefonos szolgáltatások) az összes iparág/üzletág vállalatainak müködését szinte egyidejüleg átalakította/átalakítja valamennyi 
országban (OECD, 1998). Ezen globalizációs folyamatok nagyon erőteljes versenyt generálnak, a közgazdaságtan hagyományos alapkérdéseire (,mit, hogyan és kinek”) adott válaszok kiegészülnek új szempontokkal: „,bárhonnan-bármit-bárhol-bárhová”.

A globális versenyben az iparágak többségében egyrészt az inputok sok helyről beszerezhetők, másrészt a piacok szinte mindegyik országot felölelik, ezért a vállalatok globálisan kiterjesztik tevékenységeiket, legalábbis a részlegek, kirendeltségek széles hálózatát müködtetik. Azaz bárhonnan be lehet szerezni bármilyen inputot, amit aztán szinte bárhol levő telephelyen fel lehet dolgozni és az outputot el lehet szállítani bárhová a vásárlóknak. A sztenderd inputok információ és technológiák azonnal elérhetők a globalizáció révén, míg a verseny fejlettebb dimenziói földrajzilag továbbra is lehatároltak maradnak" (Porter, 1998). Ilyen fejlettebb dimenzió közé sorolható a munkaerö vonatkozásában példának okán a $\mathrm{K}+\mathrm{F}$ tevékenység. A fentebb vázolt globalizációs folyamatok a munkaerő piacon is új kihívásokat támasztanak mind a munkáltatókkal, mind a munkavállalókkal szemben. Meglátásunk szerint a logisztika területén alkalmazott $6 \mathrm{M}$ gondolatkör az emberi erőforrás menedzsment (HRM) területén is kiválóan használható. A HRM napjaink meghatározó feladata, hogy a munkaerő a megfelelő mennyiségben, a megfelelő minőségben, a megfelelő helyen, a megfelelő időben és megfelelő költségek mellett rendelkezésre álljon. Megítélésünk szerint a globalizáció kedvező hatásai talán a munkaerö piac területén érvényesülnek a legkevésbé. Globalizáció ide vagy oda, tény, hogy a munkaerő a mai napig egy olyan sajátos termelési tényező, amely képes saját teljesítményének szabályozására. Még globális viszonyok között sem egyszerü a megfelelő munkaerő biztosítása. Egy olyan sajátos tényezö, mely megfelelő ösztönzéssel csodákat képes megvalósítani, míg rosszul kezelve az egész vállalatot a kudarc irányába terelheti.

\section{Az employer branding és annak jelentősége}

Nem csak általánosságban a világunk, hanem a HRM területén is rendkívül nagy változások mentek végbe az elmúlt években. Napjainkban a munkáltatók egyik legerősebb fegyvere a sikerességhez vezető úton egy jól felépített, erős munkáltatói márka (employer branding) kiépítése. A kifejezést az Ambler-Barrow szerzőpáros publikálta először 1996-ban. Megfogalmazásukban a munkáltatói márka nem más, mint „a munkavállalásból származó és a munkavállalóval azonosított funkcionális, gazdasági és pszichológiai előnyök összessége (...) melynek legfőbb szerepe, hogy biztosítson egy összefüggő keretet a menedzsment számára, leegyszerüsítse a folyamatokat és koncentráljon a prioritásokra, növelje a termelékenységet, javítsa, illetve fejlessze a toborzást, megtartást és elköteleződést" (Ambler-Barrow, 1996). Az employer branding nem más, mint a HR és a marketing tevékenység ötvözése (Kajos-Bálint, 2014). Korábbi, logisztika területéröl származó 6M-es adaptációnkkal élve az employer branding elsődleges feladata a megfelelő minőségü munkaerő biztosítása. A fogalom igen komplex, több tevékenységet is magában foglal, mint például a vállalat hírnevét, a munkakörnyezetet, a juttatásokat vagy a munkavállalók egészségének megörzését. A munkáltatói márka alkotóelemeinek segítségével érhetjük el azt, hogy a munkavállalók elköteleződjenek a vállalat iránt, 
élmény legyen számukra a munkavégzés (Dajnoki-Héder, 2017). Egy vállalat számára mindig fontos, hogy a külső környezete hogyan ítéli meg. Nem meglepö ebböl következően, hogy az employer branding egyfajta PR tevékenységként is felfogható. Véleményünk szerint a munkaerő piacon a $Z$ generációs fiatalok számára választási szempont többek között a vállalat hírneve és elismertsége egy-egy álláshirdetésre történő jelentkezés előtt (Fodor et al., 2017). A munkáltatói márkát nemzetgazdasági mutatók tükrében is érdemes megvizsgálni. A KSH 2020-as adatai alapján összeállított korfából látható, hogy Magyarország társadalma elöregedő társadalommá válik. Hazánkban a nyugdíjkorhatár 65 év. 2020-ban 15089965 éves ember volt Magyarországon, azonban mindössze 9880718 éves ember. Azaz láthatjuk, hogy az újonnan nyugdíjba mentek mindössze $65 \%$-át tudta volna pótolni a frissen felnőtté vált korosztály, ha egyből mindegyikük munkába áll. Ez többek között azt jelenti, hogy egyre kevesebben lépnek be a munka világába és egyre többen hagyják el azt (KSH, 2020). Egy jól felépített munkáltatói márka leginkább a magasan képzett munkaerő esetében fontos. Óriási ellentmondásnak lehetünk szemtanúi: a kevesebb születési számból adódóan egyre kevesebb a magasan képzett munkaerő (csökken a minőségi kínálat volumene), miközben a munkáltatói oldal egyre nagyobb keresletet támaszt irántuk (Kajos-Bálint, 2014). Héder-Rima és Dajnoki szavaival élve: „A szervezetek ezáltal azzal a kihívással néznek szembe, hogy a meglévő munkaerő megtartása és a potenciális munkavállalók bevonzása érdekében olyan körülményeket alakítsanak ki, mellyel biztosítani tudják a hiányzó munkaerő szervezethez való vonzódását" (Héder-Rima-Dajnoki, 2020). Agarwal és Al Qouyatahi (2017) szerint az emberi erőforrás menedzsment kulcsszerepet kapott egy globálisan müködő vállalat esetében. Észrevételünk alapján a kijelentés már egy olyan vállalat esetében is megállja a helyét, amely alapvetôen nem globális, hanem csak regionális vagy lokális színtéren tevékenykedik. A Z generáció az első globális nemzedék (Ruzsa, 2018), így tagjai attól függetlenül, hogy azonos országból származnak, alkalmazásuk okozhat olyan problémákat, mint amilyenekkel egy több országból származó alkalmazottakat foglalkoztató globális vállalat szembesül. Agarwal és Al Qouyatahi főként az eltérő kultúrákból adódó gondokat emelte ki, de a kulcs abban keresendő, hogy minden munkavállaló külön egyéniség. Úgy gondoljuk, a kijelentés különösen igaz a $Z$ generáció képviselöire, akiket erős individualizmussal szoktak jellemezni (Morning Consult, 2019). Az egyes nemzetek munkaerő piacán megjelenő $Z$ generáció úgy változtatja meg a HR tevékenységet, amint azt a globalizáció tette a nemzetközi színtérre lépő vállalatokkal. A társadalmi változások új eszközöket és módszereket tesznek szükségessé a sikerességre törekvő vállalatok életében, melynek jó eszköze lehet az erős munkáltatói márka kialakítása.

A tények pontos ismerete nélkül feltételezhetnénk, hogy minden vállalat alkalmazza az employer branding eszközeit a munkaerőpiacon. Ezzel szemben tény, hogy Magyarországon csupán minden ötödik vállalat alkalmaz a munkaerő toborzás során olyan kampányt, amely a munkáltatói minőségét hangsúlyozza, és még ennél is kevesebb vállalat fordít időt, pénzt és energiát hírnevének mérésére, nyomon követésére (Tompa, 2011). A kiválasztási folyamatok kivitelezésére nem jellemző a kiemelkedő szakmai tudás (Garai-Fodor et al., 2019). Szakirodalmi adatok alapján 
úgy gondoljuk, hogy célszerübb lenne a vállalatoknak elmélyültebben foglalkozni a módszerrel, melyet indokol az is, hogy napjainkban tapasztalható a legnagyobb generációs különbség a munkahelyek eltérő korú munkavállalói között (Garai-Fodor et al., 2019). Ahhoz, hogy egy vállalat erős munkáltatói márkát tudjon kialakítani, ismernie kell leendö munkavállalóit, melyet alátámasztanak a különböző a generációs kutatások is, amelyeket a következő fejezetben részletezünk.

\section{A Z generáció sajátosságai a munkaerő piacon}

A Z generációba tartoznak az 1996 és 2010 között születettek (Kárpáti, 2019). Más források kis eltérést mutatnak ettől: Ruzsa (2018) szerint az 1995-2009 között világra jöttek, Scroth (2019) szerint az 1997-2013 között születettek, de van olyan forrás is, ahol egyszerüen úgy jelölik öket, mint a „,90-es évek közepétöl születettek” (FeketeNagy, 2020). Nevezik még a Z generáció tagjait Facebook-nemzedéknek (FeketeNagy, 2020), ,digitális bennszülötteknek” (Kárpáti, 2019) vagy a „,netgenerációnak” (Kárpáti, 2019) is. Nem csoda, hogy ezeket a fantázianeveket adták ennek a generációnak, hiszen ez az első olyan nemzedék, amely már születésétől vagy kisgyermek korától kezdve használja az internetet és a különböző okos eszközöket (Ruzsa, 2018). Születésüktől fogva pár kattintásra vannak az azonnali kielégüléstől, ezért természetes módon, alanyi jogon mindent el akarnak érni, ráadásul azonnal. Ennek egyenes következménye, hogy különösen nehéz huzamosabb ideig fenntartani a generáció tagjainak figyelmét, hiszen ők megszokták, ha valami untatja öket, akkor azonnal tovább tudnak görgetni. Ez nem csak a márkahüség tekintetében (Ruzsa, 2018), hanem a munkavállalás esetében is problémákat, új, eddig nem tapasztalt munkavállalói reakciókat eredményez. Az alacsony létszámukból adódik az is, hogy ök születtek a legkisebb családba (Ruzsa, 2018). Ebből következik, hogy ők kapták a legtöbb szülői figyelmet és törődést, azaz a „biztonság kultúrájában” nőttek fel (Schroth, 2019). Megjelentek az úgynevezett helikopter szülök, akik ott köröznek a gyermekik fölött és minden esetben a segítségükre sietnek, amikor úgy gondolják, hogy gyermekük nem tud megbirkózni az előtte álló feladattal (JámboriKörössy, 2020). Ez a túlzottan féltő és védelmező szülői magatartás gyakran azt eredményezi, hogy az élethez szükséges alapvető készségeket nem sajátítják el a Z generáció tagjai (Schroth, 2019). Ezek alapján nem szabad meglepődnünk, hogy a generáció tagjai nem szívesen vállalnak vezetői feladatokat, félnek a felelősségtől, illetve nem gondolják magukat elég magabiztosnak a vezetéshez (Schroth, 2019). Ehhez hozzájárul az is, hogy átlagosan a gyerekek 12 éves korukban már saját okostelefonnal rendelkeznek (Ruzsa, 2018), vagyis általános iskolás koruktól kezdve a szocializációjuk az okos eszközök valamelyikének segítségével vagy éppen azok valamelyikén (lásd a COVID-19 idején történő digitális oktatásra átállás) történik. Emiatt sokukban nem alakult ki a konfliktuskezelés helyes gyakorlata, hiányoznak alapvető kommunikációs készségek, valamint az online tartalmak gyors váltakozása miatt nehézségeik támadnak az értő olvasással, a figyelem hosszabb ideig való fenntartásával (Kárpáti, 2019). Ez az a generáció, amely tagjainak a legnagyobb hajlama van a mentális problémákra és a depresszióra (Schroth, 2019). A Deloitte 2020-as felmérése alapján elmondható, hogy a megkérdezett ( $\mathrm{n}=4711,20$ országból) 
Z generációs, már dolgozó fiatalok 48\%-a érzi magát stresszesnek az idő túlnyomó részében, míg az Y generációnál ez csak 44\%. A stressz kiváltó okaként első helyen a munkahelyüket, második helyen pedig az iskolát jelölték meg. Azon fiatalok, akik jelezték, hogy az elkövetkezendő két évben munkahelyet szeretnének váltani, 15\%ban a rossz munka-magánélet egyensúlyt jelölték meg kiváltó okként. A megkérdezettek 34\%-a hagyott már ki munkanapot a stressz miatt, de ezzel kapcsolatban csak 54\%-uk volt öszinte a fönökével, vagyis 46\%-uk hazudott a távollét okát illetően. Az Y generáció mindössze 29\%-a maradt távol a munkahelytől stressz miatt, de majdnem felük nem mondta el az okot a felettesének (Deloitte, 2020). A fenti adatok is bizonyítják a probléma súlyát és aktualitását. Megállapítható, hogy az előző generációhoz képest a $Z$ generáció saját meglátása szerint gyakrabban szembesül a stresszel, viszont egyik nemzedék sem tud öszintén beszélni erről a munkáltatóval, ami szintén jelzi az employer branding szükségességét. Megállapítható az is, hogy a generáció legnagyobb problémája a „soft skills”-ek (pl. kommunikációs készség, kritikus gondolkodás, empátia) terén tapasztalható. Megítélésünk szerint a most munkába lépő generáció kezelésében az employer branding eredményes eszköz lehet, hiszen annak pontosan az a célja, hogy hosszú távú elköteleződést alakítson ki a munkavállaló és a munkáltató/vállalat között.

\section{Az employer branding szerepe a stressz csökkentésében}

Ha a Barrow és Mosley által megfogalmazott 12 employer branding elemet (Dajnoki-Héder-Rima, 2020; Barrow-Mosley, 2005) összevetjük a CooperMarshall-féle stresszorok csoportosításával (Ember, 2009, Cooper-Marshall, 1980), akkor több azonosságot is találhatunk. A munkából eredő faktorok és a szervezeti struktúra és légkör megfeleltethetőek a munkahelyi környezetnek, mint munkáltatói márka elemnek. Véleményünk szerint a szervezeti szerep és a vállalati személyiség is összefügg, hiszen egy munkavállaló csak úgy tudja kialakítani saját szerepét a szervezeten belül, ha ismeri az egész szervezet szerepét a gazdaságon belül. A munkahelyi kapcsolatok, mint stresszor egymás mellé állítható a tisztesség és együttmüködés és kommunikáció elemekkel. A karrier és fejlődés pedig megfeleltethetőek a teljesítménymenedzsment, fejlödés és jutalmazási rendszer elemekkel. Láthatjuk, hogy 8 komponens egyértelmüen kapcsolatba hozható a munkahelyi stresszel, stresszorokkal. Mindezt az alábbi, 1. ábra összegzi. 


\section{1. ábra: A munkáltató márka 12 eleme és a munkával összefüggésbe hozható stresszorok közötti kapcsolat ábrázolása}

\begin{tabular}{|c|c|}
\hline A munkáltatói márka 12 eleme & $\begin{array}{l}\text { A munkával összefüggésbe hozható } \\
\text { stresszorok csoportositása }\end{array}$ \\
\hline $\begin{array}{l}\text { o Munkahelyi környezet } \\
\text { ○ Toborzás és beillesztés } \\
\text { o Foglalkoztatást követő magatartás } \\
\text { o Külső hírnév } \\
\text { ○ Vállalati személyiség } \\
\text { o Tisztesség és együttmúködés } \\
\text { ○ Kommunikáció. } \\
\text { o Politika és értékek } \\
\text { ○ Célok és irányítás } \\
\text { ○ Teljesítménymenedzsment } \\
\text { ○ Fejlódés } \\
\text { ○ Jutalmazási rendszer }\end{array}$ & $\begin{array}{l}\text { A munkából eredő faktor } \\
\text { (munkafeltételek, túlterhelés a } \\
\text { munkában) } \\
\text { A szervezeti struktúra és légkör } \\
\text { O Szervezeti szerep (szerep kétértelmüség, } \\
\text { szerepkonfliktus, felelősség, más szerep } \\
\text { stresszorok) } \\
\text { Munkahelyi kapcsolatok (kapcsolat a } \\
\text { feletessel, kapcsolat a beosztottal, } \\
\text { kapcsolat a kollégákkal) } \\
\text { Karrier (fejlödés) (stabilitás hiánya, a } \\
\text { státusz inkongruitás) } \\
\text { O A szervezeten kívüli stressz } \\
\text { O A szervezet, mint stressz }\end{array}$ \\
\hline
\end{tabular}

Forrás: A szerzők saját szerkesztése Barrow-Moesley (2005), Cooper-Marshall (1980) alapján

A munkavállalók egészségével a múlt század végéig nem foglalkoztak kiemelten, mivel úgy gondolták a munkaadók, hogy ennél fontosabb a teljesítmény. A század végére felismerték, hogy a munkavállaló egészsége szoros korrelációt mutat teljesítményével. Belátták, hogy a munkavállalók jó egészsége mindkét fél számára kölcsönös előnyöket hordoz magában. Az egészséges munkavállaló ezen túlmenően a társadalom számára is közvetetten hasznos, hiszen javítja a nemzetgazdaság teljesítményét (Haffner-Bárdos, 2019). Staglin 2019-es kutatása szerint a depresszió és a szorongás miatt csökkenő termelékenység 1 billió dollárjába kerül a világnak évente (Szabó-Juhász, 2020). Fontos azonban látnunk, hogy a munkahelyi stressz nem csupán a munkáltatón múlik, hanem legalább ennyire múlik a munkavállalón is. A munkavállaló életvitele nagyban hozzájárul ahhoz, hogyan képes kezelni a munkahelyén őt érő ingereket. A WHO 1998-as definíciója szerint az egészség nem csak a betegség hiányát jelenti, hanem a fizikai, szellemi és szociális jóllét állapotát (Szabó-Juhász, 2020). Hiába próbál egy vállat stresszmentes feltételeket biztosítani, ha a munkavállalók alig tesznek a saját egészségük védelméért. Az OECD 2019-es jelentésből kiderül, hogy Magyarország vezető helyet foglal el a dohányzásban, elhízásban és alkoholfogyasztásban. A munkáltatók számára elengedhetetlen lenne dolgozóikat az egészséges életvitel felé terelniük, hiszen „az emberi erőforrás minden müködő gazdasági tevékenység alfája és ómegája" (Bertalan-Boldizsár, 2015).

A stressz rövid és hosszú távon is okozhat problémákat az embereknél. Rövid távon beszélhetünk állapot vagy hangulatváltozásokról, mint pl. a harag vagy a feszültség, melyekhez átmeneti fiziológiai változások társulnak, pl. pulzus emelkedés. Hosszú távon pszichológiai válaszreakciók alakulhatnak ki, úgy, mint a depresszió, melyeket különböző betegségek kísérhetnek, pl. a szívproblémák. A 
nyilvánvaló egészségügyi károsodásokon túl a munkahelyi stressz a vállalatnak is több gondot okoz, hiszen a kimerült, beteg dolgozónak csökken a teljesítménye vagy akár kiesik a munkából (Haffner-Bárdos, 2019).

Meglátásunk szerint, nem szabad a stresszre kizárólagosan negatív dologként tekintenünk. Selye János (1976) a stresszkutatás atyja is úgy fogalmazott, hogy „a stressz az élet sava-borsa.”. Selye szerint megkülönböztethetünk jó és rossz stresszt. A ,jó stressz" motivál és nem akadályozza a munkavállalót. Ha az előttük álló feladatra nem akadályként, hanem kihívásként tekintenek, pozitív kimenetelü lesz a feladat, ami által fejlődni tudnak és növekszik az elköteleződésük a cég felé. (Haffner-Bárdos, 2019) Ez különösen fontos lehet a Z generáció munkavállalói számára, mivel az employer brandingnek pont az a fö feladata, hogy elköteleződést alakítson ki a munkavállaló és a vállalat között. Az employer branding ezen feladatát össze lehet és kell hangolni azzal, hogy csökkentsük a munkahelyi stresszt és megváltoztassuk a munkavállalók stresszhez való hozzáállását. El kell érni azt, hogy a munkavállaló egy-egy jelentősebb feladatra ne problémaként tekintsen, hanem szakmai fejlődését segítő kihívásként. Ebben kiemelt feladata van a munkahelyi kultúrának, illetve az employer brandingnek is. Ennek elérése még égetőbb annak tükrében, hogy a $Z$ generáció készül belépni, illetve részben már belépett a munkaerö piacra. A feladat kihívás konverzió megvalósítása annál is inkább fontos, mert az összes eddigi generáció közül a $Z$ generáció a leginkább hajlamos szorongásra és depresszióra.

\section{Következtetések, összegzés, záró megjegyzések, záró gondolatok}

A nemzetgazdasági mutatók tükrében a munkáltatókon egyértelmüen egyre nagyobb a teher annak vonatkozásában, hogy vonzó munkafeltételeket tudjanak nyújtani a munkaerő piacra már belépett vagy belépni készülő $Z$ generációs fiatalok számára. Az eddigi nemzedékekhez képest egy teljesen újfajta szociálizációs mintát mutató korcsoportról beszélünk, hiszen ők voltak azok, akiknek a gyermekkoruk szerves részét képezte az internet és az okoseszközök használata. A munkáltatóknak fokozott figyelmet kell fordítaniuk a pályakezdő munkavállalóikra, hiszen kutatások igazolják, hogy ők a leginkább hajlamosak a szorongásra, érdeklődésüket hamar elveszítik. Fontos számukra a folyamatos visszajelzés munkájukat illetően. Erre kiváló eszköz lehet az employer branding használata, amit ma még sok vállalat nem alkalmaz a mindennapokban. A szakirodalom egyértelmủen alátámasztja, hogy egy erős munkáltatói márka kialakításával nagyobb elköteleződés alakítható ki a munkáltató irányába, vagyis csökken a fluktuáció mértéke. Egész egyszerüen a munkáltató szívesebben fog a munkahelyére bejárni, hatékonyabban fog ott dolgozni. A szekunder adatok alapján úgy látjuk, hogy a munkáltatóknak fontos azt felismerni, hogy milyen elönyöket jelent számukra az employer branding alkalmazása. Az employer branding alkalmazása természetesen nem csak a Z generáció, hanem az idősebb korosztály foglalkoztatásában is pozitív kimenetelü lehet. Kutatásunk jövőbeli irányvonalát képezi egy önálló, primer kutatás lefolytatása. A primer kutatás arra keresi majd a választ, hogy az employer branding 
hogyan és milyen mértékben képes a munkahelyi stresszt kezelni, a szakirodalmi adatok és módszerek hogyan és milyen mértékben ültethetők át a gyakorlatba.

\section{Irodalomjegyzék}

Agarwal., S., Al Qouyatahi., K. M. S. (2017): HRM Challenges in the Age of Globalisation, International Research Journal of Business Studies, 10 (2): 89-98.

Ambler, T., Barrow, S. (1996): The Employer Brand. The Journal of Brand Management, 4 (3 December): 185-206.

Barrow, S., Mosley, R. (2005): The Employer Brand. Bringing the Best of Brand Management to People at Work. John Wiley \& Sons Ltd., Chichester.

Bertalan P., Boldizsár B. (2015): Globális trendek és a HR. Acta Scientiarum Socialium, (44): 151160.

Cooper, C. L., Marshall, J. (1980): White Collar and Professional Stress. Wiley. New York.

Dajnoki K., Héder M. (2017): „Új szelek fújnak” - a HR válasza a globalizáció és a változás kihívásaira. Hadtudomány, 27: 84-93.

Dajnoki K., Héder-Rima M. (2020): A munkáltatói márka meghatározása és szlogen alapú értelmezése. Jelenkori társadalmi és gazdasági folyamatok, 15 (3-4): 93-106.

Deloitte (2020): Millennials, Gen $Z$ and mental health. $<$ https://www2.deloitte.com/content/dam/Deloitte/global/Documents/About-Deloitte/gxmillennial-survey-mental-health-whitepaper.pdf $>$ (2021.03.08.)

Ember A. (2009): A munkahelyi stressz, mint a leggyakoribb modern foglalkozási megbetegedés. Acta Sana, 4 (2): 15-23.

Fekete M., Nagy Á. (2020): Vitaindító: Megszólal-e az új csendes generáció? Avagy mit várhatunk az Ifjúság 2020 adatfelvétel eredményeképp. Szociológiai Szemle, 30 (1): 98-106.

Fodor M., Jäckel K., Nagy O. (2017): Employer Branding a Z generáció szemével - Milyen munkahelyre vágynak és milyen szempontok alapján döntenek a munkahelyválasztásról a "Zk”, Tanulmánykötet -Vállalkozásfejlesztés a XXI. Században, 7: 145-153.

Garai-Fodor M., Jäckel K., Almádi B.,Szemere T. P. (2019): The role of employer branding for generation $\mathrm{Z}$ based on HR expert interviews and their effects on the implementation of investments. Tér-Gazdaság-Ember, 4 (7): 167-179.

Haffner O., Bárdos Gy. (2019): A stressz megjelenési formái állásinterjún és a munkahelyen. Tudásmenedzsment, 20 (1): 42-46.

Héder-Rima M., Dajnoki K. (2020): Kultúrám a márkám - A munkáltatói márkaépítés és a szervezeti kultúra kapcsolata. Marketing és Menedzsment, 54 (2): 5-15.

Jámbori Sz., Kőrőssy J. (2020): Észlelt szülői nevelés a fiataloknál: társas és társadalmi hatások. Magyar Pszichológiai Szemle, 75 (2/13): 193-215.

Kajos A., Bálint B. (2014): A marketingszemlélet és a HR találkozása. Vezetéstudomány, 45 (6): 6979.

Kárpáti L. (2019): Gondolatok a Z-generáció társas jellemzőiről és ezek lehetséges társadalmi hatásairól. Közelítések, 2019: (3-4): 77-91.

KSH (2020): Magyarország népességének száma nemek és életkor szerint. $<$ https://www.ksh.hu/interaktiv/korfak/orszag.html> (2021. 02. 21.)

Lengyel I. (2003): Verseny és területi fejlödés. JATEPress, Szeged.

Morning Consult (2019): Understanding Gen Z. <https://morningconsult.com/wpcontent/uploads/2019/06/Morning-Consult-Understanding-Gen-Z.pdf> (2021.03.08.)

OECD (1998): Industrial performance and Competitiveness in an Era of Globalization and $\begin{array}{llll}\text { Technological Change } & \text { OECD } & \text { DSTI/IND(97)23. } & \text { Paris. }\end{array}$ $<$ https://www.oecd.org/sti/ind/2090669.pdf $>$ (2021. 02. 21.)

OECD (2019): State of Health in the EU- Hungary - Country Healt Profile 2019. <https://www.oecdilibrary.org/docserver/4b7ba48c-

en.pdf? expires $=1613921277 \& \mathrm{id}=\mathrm{id} \&$ accname $=$ guest\&checksum $=$ E5 AED31 A59CF1FE144FB 92F4EB07A40F $>$ (2021. 02. 21.) 
Porter, M. E.(1998): On Competition. Harvard Business School Pr.

Ruzsa Cs. R. (2018): „Z” generáció fö jellemzői és a várható munkaerő-piaci kihívások. KözépEurópai Közlemények, 11 (3): 149-157.

Schroth, H. (2019): Are You Ready for Gen Z in the Workplace?. California Management Review, $61(3): 5-18$.

Selye J. (1976): Stressz distressz nélkül. Akadémiai Kiadó. Budapest.

Staglin, G. (2019): Why Mental Health Is An Executive Priority. $<$ https://www.forbes.com/sites/onemind/2019/03/18/why-mental-health-is-an-executivepriority/?sh=7b5c3abe5bb4> (2021.03.08.)

Szabó Á., Juhász P. (2020): Teremthet az életmód orvostan tulajdonosi és munkavállalói értéket egyidőben?, Köz-gazdaság, 15 (2): 180 - 202.

Tompa N. (2011): A munkáltatói márkaépítés jelentősége. Munkaügyi szemle, 4: 21-24. (1998):

Health

Promotion

Glossary

$<$ https://www.who.int/healthpromotion/about/HPR\%20Glossary\%201998.pdfua=1

(2021.03.08.) 